\title{
Bromate Formation Characteristics of UV Irradiation, Hydrogen Peroxide Addition, Ozonation, and Their Combination Processes
}

\author{
Naoyuki Kishimoto ${ }^{1}$ and Eri Nakamura ${ }^{2}$ \\ ${ }^{1}$ Faculty of Science and Technology, Ryukoku University, 1-5 Yokotani, Setaoe-cho, Otsu 520-2194, Japan \\ ${ }^{2}$ Graduate School of Science and Technology, Ryukoku University, 1-5 Yokotani, Setaoe-cho, Otsu 520-2194, Japan \\ Correspondence should be addressed to Naoyuki Kishimoto, naoyuki@rins.ryukoku.ac.jp
}

Received 28 May 2012; Revised 8 August 2012; Accepted 8 August 2012

Academic Editor: Manickavachagam Muruganandham

Copyright (C) 2012 N. Kishimoto and E. Nakamura. This is an open access article distributed under the Creative Commons Attribution License, which permits unrestricted use, distribution, and reproduction in any medium, provided the original work is properly cited.

\begin{abstract}
Bromate formation characteristics of six-physicochemical oxidation processes, UV irradiation, single addition of hydrogen peroxide, ozonation, UV irradiation with hydrogen peroxide addition $\left(\mathrm{UV} / \mathrm{H}_{2} \mathrm{O}_{2}\right)$, ozonation with hydrogen peroxide addition $\left(\mathrm{O}_{3} /\right.$ $\mathrm{H}_{2} \mathrm{O}_{2}$ ), and ozonation with UV irradiation $\left(\mathrm{O}_{3} / \mathrm{UV}\right)$ were investigated using $1.88 \mu \mathrm{M}$ of potassium bromide solution with or without $6.4 \mu \mathrm{M}$ of 4-chlorobenzoic acid. Bromate was not detected during $\mathrm{UV}$ irradiation, single addition of $\mathrm{H}_{2} \mathrm{O}_{2}$, and $\mathrm{UV} / \mathrm{H}_{2} \mathrm{O}_{2}$, whereas ozone-based treatments produced $\mathrm{BrO}_{3}{ }^{-}$. Hydroxyl radicals played more important role in bromate formation than molecular ozone. Acidification and addition of radical scavengers such as 4-chlorobenzoic acid were effective in inhibiting bromate formation during the ozone-based treatments because of inhibition of hydroxyl radical generation and consumption of hydroxyl radicals, respectively. The $\mathrm{H}_{2} \mathrm{O}_{2}$ addition was unable to decompose 4-chlorobenzoic acid, though $\mathrm{O}_{3} / \mathrm{UV}$ and $\mathrm{O}_{3} / \mathrm{H}_{2} \mathrm{O}_{2}$ showed the rapid degradation, and $\mathrm{UV}$ irradiation and $\mathrm{UV} / \mathrm{H}_{2} \mathrm{O}_{2}$ showed the slow degradation. Consequently, if the concentration of organic contaminants is low, the UV irradiation and/or $\mathrm{UV} / \mathrm{H}_{2} \mathrm{O}_{2}$ are applicable to organic contaminants removal without bromate formation. However, if the concentration of organic contaminants is high, $\mathrm{O}_{3} / \mathrm{H}_{2} \mathrm{O}_{2}$ and $\mathrm{O}_{3} / \mathrm{UV}$ should be discussed as advanced oxidation processes because of their high organic removal efficiency and low bromate formation potential at the optimum condition.
\end{abstract}

\section{Introduction}

Nowadays, the world demand for water is growing because of the rapid population growth. Furthermore, pollution of freshwater resources proceeds in all over the world. For instance, China encounters severe water pollution caused by industrial chemicals, heavy metals, and algal toxin with an extraordinary economic growth [1]. Gadgil [2] reported that about half the population in the developing world is suffering from one or more of the six main diseases, diarrhea, ascaris dracunculisis, hookworm, schistosomiasis, and trachoma, which are associated with water supply and sanitation. In the industrialized countries, micropollutants like pharmaceuticals gather much concern as potential contaminants in drinking water [3] and surface water [4]. As a result of this situation, water supply section has made efforts to supply a plenty of safe drinking water. In this context, various advanced water treatment like UV disinfection, ozonation, and adsorption processes [5-7] have been introduced to water purification plants.

UV irradiation and ozone-based chemical oxidation are widely used as advanced water purification processes. These processes can achieve higher level of disinfection and organic pollutants removal $[9,10]$. However, bromate $\left(\mathrm{BrO}_{3}{ }^{-}\right)$ formation in these chemical oxidation processes may bring a potential health risk, because $\mathrm{BrO}_{3}{ }^{-}$is a possibly carcinogenic to human [11]. Therefore, it is important to understand $\mathrm{BrO}_{3}{ }^{-}$formation potential in these processes.

Various knowledge of the $\mathrm{BrO}_{3}{ }^{-}$formation during $\mathrm{UV}$ and ozone-based chemical oxidation processes has been accumulated for past a few decades. For instance, ozonation of bromide-containing water produces $\mathrm{BrO}_{3}{ }^{-}$via ozone and 
hydroxyl radical pathways [8], but $\mathrm{pH}$ depression [12] and ammonia addition $[12,13]$ successfully decrease $\mathrm{BrO}_{3}{ }^{-}$ formation. The $\mathrm{pH}$ depression decreased $50-63 \%$ in $\mathrm{BrO}_{3}{ }^{-}$ formation per a decline in one-pH-unit [12] because of a depression of hydroxyl radical generation and a decrease in hypobromite $\left(\mathrm{BrO}^{-}\right)$, which is a key intermediate of $\mathrm{BrO}_{3}{ }^{-}$ formation. The inhibition effect of ammonia addition on $\mathrm{BrO}_{3}{ }^{-}$formation is caused by bromamines formation from the reaction of $\mathrm{HOBr}$ with ammonia [14]. The effective ammonia dose for $\mathrm{BrO}_{3}{ }^{-}$depression was limited to $200 \mu \mathrm{g} / \mathrm{L}$ and further increase in ammonia addition did not enhance the $\mathrm{BrO}_{3}{ }^{-}$minimization [14]. Effect of hydrogen peroxide $\left(\mathrm{H}_{2} \mathrm{O}_{2}\right)$ in ozonation on $\mathrm{BrO}_{3}{ }^{-}$formation is complicated. As $\mathrm{H}_{2} \mathrm{O}_{2}$ can reduce $\mathrm{BrO}^{-}$into bromide $\left(\mathrm{Br}^{-}\right)$[15], it seems to be useful to depress the $\mathrm{BrO}_{3}{ }^{-}$formation. However, ozone reacts with hydroperoxide anion $\left(\mathrm{HO}_{2}{ }^{-}\right)$and produces hydroxyl radicals $\left(\bullet^{\circ} \mathrm{OH}\right)[16]$, which promotes oxidation of $\mathrm{Br}^{-}$ [8]. Ozekin et al. [13] reported that an increase in $\mathrm{H}_{2} \mathrm{O}_{2}$ dose in ozonized water enhanced $\mathrm{BrO}_{3}{ }^{-}$formation at $\mathrm{pH}$ 6.5 , though the $\mathrm{BrO}_{3}{ }^{-}$formation at $\mathrm{pH} 8.5$ did not depended on the $\mathrm{H}_{2} \mathrm{O}_{2}$ dose and was smaller than that of ozone alone. Kim et al. [17] pointed out the importance of molar ratio of $\mathrm{H}_{2} \mathrm{O}_{2} / \mathrm{O}_{3}$ for $\mathrm{BrO}_{3}{ }^{-}$formation during ozonation with $\mathrm{H}_{2} \mathrm{O}_{2}$ addition; the molar ratio of $\mathrm{H}_{2} \mathrm{O}_{2} / \mathrm{O}_{3}$ above 0.5 and the dissolved ozone concentration below $0.1 \mathrm{mg} / \mathrm{L}$ successfully depress the $\mathrm{BrO}_{3}{ }^{-}$formation. The inconsistent results between Ozekin et al. [13] and Kim et al. [17] may be caused by the difference in their experimental designs: $\mathrm{H}_{2} \mathrm{O}_{2}$ was injected during ozonation [17] or after ozonation [13]. But, both research groups suggested that the $\cdot \mathrm{OH}$ generation under a certain concentration of dissolved ozone enhanced the $\mathrm{BrO}_{3}{ }^{-}$formation during ozone $/ \mathrm{H}_{2} \mathrm{O}_{2}$ treatment $[13,17]$. UV light is known to decompose $\mathrm{BrO}_{3}{ }^{-}$into $\mathrm{BrO}^{-}$and/ or $\mathrm{Br}^{-}$[18]. As the result, Collivignarelli and Sorlini [19] reported that $\mathrm{BrO}_{3}{ }^{-}$formation during ozonation with UV $254 \mathrm{~nm}$ irradiation $\left(\mathrm{O}_{3} / \mathrm{UV}\right)$ was about $40 \%$ lower than that during conventional ozonation. However, Ratpukdi et al. [20] showed that the $\mathrm{BrO}_{3}{ }^{-}$formation potential of $\mathrm{O}_{3} / \mathrm{UV}$ was similar to ozonation alone, though ozonation combined with vacuum UV irradiation could decrease the $\mathrm{BrO}_{3}{ }^{-}$ formation. Thus, the $\mathrm{BrO}_{3}{ }^{-}$formation mechanisms of UV and ozone-based chemical oxidation processes have been explored extensively. However, each research was performed using different reactors, different procedures, and different water matrices. Therefore, it is not easy to judge which process should be selected for $\mathrm{BrO}_{3}{ }^{-}$control.

In this study, $\mathrm{BrO}_{3}{ }^{-}$formation in UV irradiation, $\mathrm{H}_{2} \mathrm{O}_{2}$ addition, ozonation, and their combination processes, UV irradiation with $\mathrm{H}_{2} \mathrm{O}_{2}$ addition ( $\mathrm{UV} / \mathrm{H}_{2} \mathrm{O}_{2}$ ), ozonation with $\mathrm{H}_{2} \mathrm{O}_{2}$ addition $\left(\mathrm{O}_{3} / \mathrm{H}_{2} \mathrm{O}_{2}\right)$, and ozonation with UV irradiation $\left(\mathrm{O}_{3} / \mathrm{UV}\right)$, were discussed using the same reactor and the same water matrix to provide comparable information of their features of $\mathrm{BrO}_{3}{ }^{-}$formation and its control.

\section{Experimental}

2.1. Material and Experimental Conditions. A low-pressure mercury vapor lamp (20W, UVL20PH-6, Sen Lights, Japan) was used as a UV light source. Ozone gas was generated from analytical grade oxygen gas with a silent discharge ozonizer (ED-OG-R3Lt, Eco Design, Japan). Hydrogen peroxide was purchased from Nacalai Tesque, Japan as about 35\% aqueous solution (extra pure grade) and used without further purification. The accurate $\mathrm{H}_{2} \mathrm{O}_{2}$ concentration was checked just before an experiment and final concentration was set at 10,100 , or $1,000 \mu \mathrm{M}$. Figure 1 shows the experimental setup. The reactor was made of glass with a volume of $1.9 \mathrm{~L}$. The UV lamp in a duplex quartz jacket was installed in the center of the reactor. Ozone was injected through two gas diffusers made of glass at the injection rate of about $20 \mathrm{mg} / \mathrm{min}$. Inlet and outlet ozone gas concentration was monitored with two ozone monitors (EG-600, Ebara Jitsugyo, Japan). The exhaust ozone gas was dried with a gas dryer (DH106-1, Komatsu Electronics, Japan) before ozone monitoring, because water vapor biases the ozone concentration. Oxygen gas flow rate was regulated with a mass flow controller (CMQ9200, Yamatake, Japan) at $500 \mathrm{~mL} / \mathrm{min}$. Test solution was $1.9 \mathrm{~L}$ of $1.88 \mu \mathrm{M}$ potassium bromide $(\mathrm{KBr}$, Nacalai Tesque, Japan) solution with or without $6.4 \mu \mathrm{M}$ of 4-chlorobenzoic acid (4-CBA, Wako Chemicals, Japan). The 4-CBA was used as a model compound of organic scavengers of hydroxyl radical $\left(\bullet^{\circ} \mathrm{OH}\right)$, because it was unreactive with ozone [21]. The solution $\mathrm{pH}$ was adjusted by addition of sulfuric acid or sodium hydroxide at around 2.5 or 7 . An experimental run continued for 10 or 30 minutes and solution in the reactor was sampled every two or five minutes for chemical analyses of $\mathrm{BrO}_{3}{ }^{-}$, bromide ion $\left(\mathrm{Br}^{-}\right)$, dissolved ozone, $\mathrm{H}_{2} \mathrm{O}_{2}, 4-\mathrm{CBA}$, and $\mathrm{pH}$.

2.2. Chemical Analysis. The $\mathrm{Br}^{-}$concentration was analyzed using an ion chromatography system with a conductivity detector (DX-500, Dionex, USA). Analytical conditions were as follows. Column: Dionex IonPac AS12A with a suppressor (Dionex ASRS-ULTRA $4 \mathrm{~mm}$ ); mobile phase: aqueous solution with $2.7 \mathrm{mM}$ sodium carbonate and $0.3 \mathrm{mM}$ sodium bicarbonate; flow rate: $1.0 \mathrm{~mL} / \mathrm{min}$; sample injection volume: $100 \mu \mathrm{L}$; oven temperature: $40^{\circ} \mathrm{C}$. The $\mathrm{BrO}_{3}{ }^{-}$concentration was determined by the ion chromatography coupled with a postcolumn system (Dionex BRS-500) [22]. Reaction conditions were as follows, reactant $\mathrm{A}: 1.5 \mathrm{M}$ potassium bromide and $1.0 \mathrm{M}$ sulfuric acid; reactant $\mathrm{B}: 1.2 \mathrm{mM}$ sodium nitrite; flow rate: $0.4 \mathrm{~mL} / \mathrm{min}$ for reactant $\mathrm{A}$ and $0.2 \mathrm{~mL} / \mathrm{min}$ for reactant $\mathrm{B}$; reaction temperature: $40^{\circ} \mathrm{C}$; detection: absorbance at $268 \mathrm{~nm}$. The determination limit was estimated to be $0.050 \mu \mathrm{M}$. Dissolved ozone and $\mathrm{H}_{2} \mathrm{O}_{2}$ were analyzed by indigo-colorimetric method [23] and DMP method [24], respectively. The 4-CBA concentration was determined by the high-performance liquid chromatography (LV-10ADVP, Shimadzu, Japan) [21]. Analytical conditions were as follows: column: ODS-80TM $(4.6 \times 250 \mathrm{~mm}$, Tosoh, Japan); mobile phase: acetonitrile (70\%) and $0.1 \%$ phosphoric acid $(30 \%)$; flow rate: $1.0 \mathrm{~mL} / \mathrm{min}$; sample injection volume: $200 \mu \mathrm{L}$; oven temperature: $40^{\circ} \mathrm{C}$; detection: absorbance at $234 \mathrm{~nm}$. The solution $\mathrm{pH}$ was measured with a $\mathrm{pH}$ meter (Twin pH B-212, Horiba, Japan). 


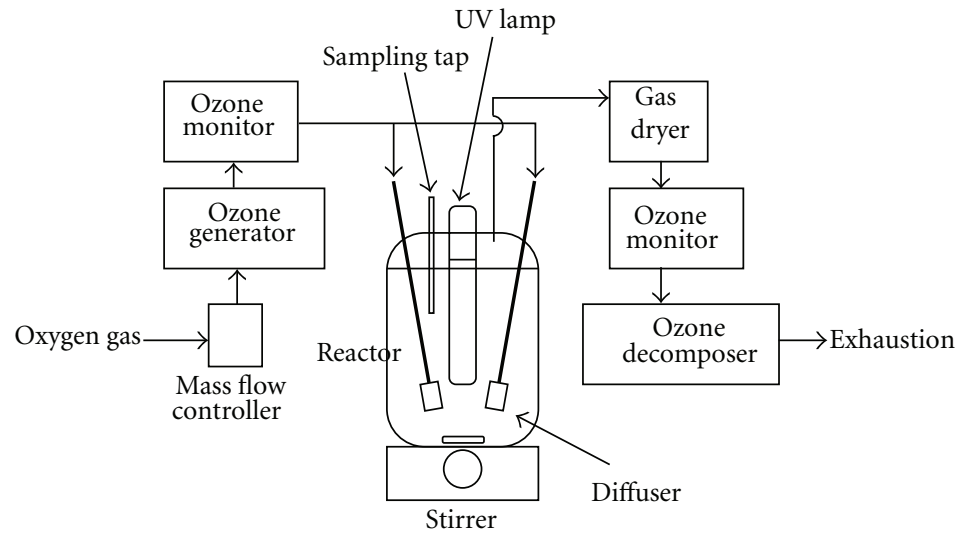

Figure 1: Experimental setup.

\section{Results and Discussion}

3.1. UV Irradiation, $\mathrm{H}_{2} \mathrm{O}_{2}$ Addition, and $\mathrm{UV} / \mathrm{H}_{2} \mathrm{O}_{2}$ Process. The $\mathrm{H}_{2} \mathrm{O}_{2}$ addition did not change concentrations of $\mathrm{BrO}_{3}{ }^{-}$, $\mathrm{Br}^{-}$, and 4-CBA under both acid and neutral $\mathrm{pH}$ conditions (data not shown). Although $\mathrm{H}_{2} \mathrm{O}_{2}$ is an oxidant, $\mathrm{H}_{2} \mathrm{O}_{2}$ is nucleophilic too. Therefore, $\mathrm{H}_{2} \mathrm{O}_{2}$ can oxidize $\mathrm{Br}^{-}$into bromine $\left(\mathrm{Br}_{2}\right)$, but $\mathrm{Br}_{2}$ is reduced into $\mathrm{Br}^{-}$by $\mathrm{H}_{2} \mathrm{O}_{2}$ as follows [25]:

$$
\begin{gathered}
2 \mathrm{Br}^{-}+\mathrm{H}_{2} \mathrm{O}_{2}+2 \mathrm{H}^{+} \longrightarrow \mathrm{Br}_{2}+2 \mathrm{H}_{2} \mathrm{O} \\
\mathrm{Br}_{2}+\mathrm{H}_{2} \mathrm{O}_{2} \longrightarrow 2 \mathrm{H}^{+}+2 \mathrm{Br}^{-}+\mathrm{O}_{2}
\end{gathered}
$$

Accordingly, $\mathrm{Br}^{-}$concentration did not change because of the catalytic behavior of $\mathrm{Br}^{-}$as shown in reactions (1). On the reactivity of 4-CBA with $\mathrm{H}_{2} \mathrm{O}_{2}$, Dionysiou et al. [26] also observed that $\mathrm{H}_{2} \mathrm{O}_{2}$ did not decompose 4-CBA under the dark condition. Since the standard electrode potential of $\mathrm{H}_{2} \mathrm{O}_{2}$ (1.736 V versus standard hydrogen electrode (SHE)) is lower than that of ozone $(2.07 \mathrm{~V}$ versus $\mathrm{SHE})$ and ${ }^{\bullet} \mathrm{OH}$ (2.38 V versus SHE) [25], the low oxidation potential of $\mathrm{H}_{2} \mathrm{O}_{2}$ may be responsible for the low reactivity with 4-CBA.

Figure 2 shows the time-course changes in $\mathrm{Br}^{-}, \mathrm{BrO}_{3}{ }^{-}$, and 4-CBA concentrations during UV irradiation and UV/ $\mathrm{H}_{2} \mathrm{O}_{2}$ at neutral $\mathrm{pH}$. The concentration changes at acidic condition were almost the same at neutral $\mathrm{pH}$, though the $\mathrm{H}_{2} \mathrm{O}_{2}$ accumulation was enhanced at acidic condition. The low-pressure mercury vapor lamp emits vacuum UV light of $185 \mathrm{~nm}$, which can photolyze water molecules into hydrogen atoms and $\cdot \mathrm{OH}$ [27]. Therefore, $\mathrm{H}_{2} \mathrm{O}_{2}$ accumulation was caused by $\mathrm{H}_{2} \mathrm{O}_{2}$ production via the combination of two - $\mathrm{OH}$ [28]. The concentrations of $\mathrm{Br}^{-}$and 4-CBA declined during the $\mathrm{UV}$ irradiation and $\mathrm{UV} / \mathrm{H}_{2} \mathrm{O}_{2}$, though $\mathrm{BrO}_{3}{ }^{-}$ was not generated (Figure 2). $\mathrm{No}_{\mathrm{BrO}_{3}}{ }^{-}$formation during $\mathrm{UV}$ irradiation and $\mathrm{UV} / \mathrm{H}_{2} \mathrm{O}_{2}$ was also reported by Kruithof et al. [29]. The $\mathrm{H}_{2} \mathrm{O}_{2}$ concentration in the both treatment increased with the passage of time, and the final concentration in UV irradiation reached over $10 \mu \mathrm{M}$, which was the initial concentration in $\mathrm{UV} / \mathrm{H}_{2} \mathrm{O}_{2}$. The 4-CBA degradation in UV irradiation slightly delayed in comparison with that in $\mathrm{UV} / \mathrm{H}_{2} \mathrm{O}_{2}$, but the degradation was enhanced with the accumulation of $\mathrm{H}_{2} \mathrm{O}_{2}$. Accordingly, ${ }^{\circ} \mathrm{OH}$ generation via
UV photolysis of $\mathrm{H}_{2} \mathrm{O}_{2}$ [27] was believed to contribute to the 4-CBA degradation during the UV irradiation and UV/ $\mathrm{H}_{2} \mathrm{O}_{2}$. The decline in $\mathrm{Br}^{-}$concentration without $\mathrm{BrO}_{3}{ }^{-}$ accumulation indicates the formation of intermediates. Von Gunten and Oliveras [8] reported that ozone and $\bullet \mathrm{OH}$ oxidized $\mathrm{Br}^{-}$to $\mathrm{BrO}_{3}^{-}$(Figure 3 ). In this mechanism, hypobromite ion $\left(\mathrm{BrO}^{-}\right)$and bromite ion $\left(\mathrm{BrO}_{2}{ }^{-}\right)$are the critical intermediates, which participate in all $\mathrm{BrO}_{3}{ }^{-}$formation pathways. Accordingly, UV irradiation and $\mathrm{UV} / \mathrm{H}_{2} \mathrm{O}_{2}$ were thought to produce $\mathrm{BrO}^{-}$and/or $\mathrm{BrO}_{2}{ }^{-}$. The $\mathrm{H}_{2} \mathrm{O}_{2}$ can reduce hypobromous acid $(\mathrm{HOBr})$ and $\mathrm{BrO}^{-}$as follows [15]:

$$
\begin{aligned}
\mathrm{BrO}^{-}+\mathrm{H}_{2} \mathrm{O}_{2} & \longrightarrow \mathrm{Br}^{-}+\mathrm{H}_{2} \mathrm{O}+\mathrm{O}_{2} \\
k & =1.3 \times 10^{6} \mathrm{M}^{-1} \mathrm{~s}^{-1}, \\
\mathrm{HOBr}+\mathrm{HO}_{2}{ }^{-} & \longrightarrow \mathrm{Br}^{-}+\mathrm{H}_{2} \mathrm{O}+\mathrm{O}_{2} \\
k & =7.6 \times 10^{8} \mathrm{M}^{-1} \mathrm{~s}^{-1}, \\
\mathrm{HOBr}+\mathrm{H}_{2} \mathrm{O}_{2} \longrightarrow & \mathrm{Br}^{-}+\mathrm{H}^{+}+\mathrm{H}_{2} \mathrm{O}+\mathrm{O}_{2} \\
k & =1.5 \times 10^{4} \mathrm{M}^{-1} \mathrm{~s}^{-1} .
\end{aligned}
$$

Therefore, the accumulation of $\mathrm{H}_{2} \mathrm{O}_{2}$ was inferred to contribute partly to the prevention of $\mathrm{BrO}_{3}{ }^{-}$formation in $\mathrm{UV}$ irradiation and $\mathrm{UV} / \mathrm{H}_{2} \mathrm{O}_{2}$. Phillip et al. [30] reported that low-pressure mercury vapor lamps decayed free bromine into $\mathrm{Br}^{-}$(major) and $\mathrm{BrO}_{3}{ }^{-}$(minor). Thus, the photo-degradation of $\mathrm{HOBr} / \mathrm{BrO}^{-}$might conduce to the prevention of $\mathrm{BrO}_{3}{ }^{-}$formation too.

3.2. Ozonation. In ozonation, $\mathrm{BrO}_{3}{ }^{-}$formation was correspondent to a decrement in $\mathrm{Br}^{-}$at neutral $\mathrm{pH}$ without 4$\mathrm{CBA}$. However, the $\mathrm{BrO}_{3}{ }^{-}$formation was much lower than $\mathrm{Br}^{-}$removal at acidic $\mathrm{pH}$ or coexistence of 4-CBA (Figure 4). Although both ozone and ${ }^{\circ} \mathrm{OH}$ promote the oxidation of $\mathrm{Br}^{-}$ to $\mathrm{BrO}_{3}{ }^{-}$via $\mathrm{BrO}^{-}$and $\mathrm{BrO}_{2}{ }^{-}$(Figure 3), our experimental results shown in Figure 4 indicated that contribution of ${ }^{\bullet} \mathrm{OH}$ to $\mathrm{BrO}_{3}{ }^{-}$evolution was relatively large. Because acidic $\mathrm{pH}$ restrains ${ }^{\bullet} \mathrm{OH}$ generation via self-decomposition of ozone [31], and 4-CBA is a $\cdot \mathrm{OH}$ radical scavenger with low reactivity with ozone [21]. Since HOBr has a pKa of 8.8-9.0 [32], 


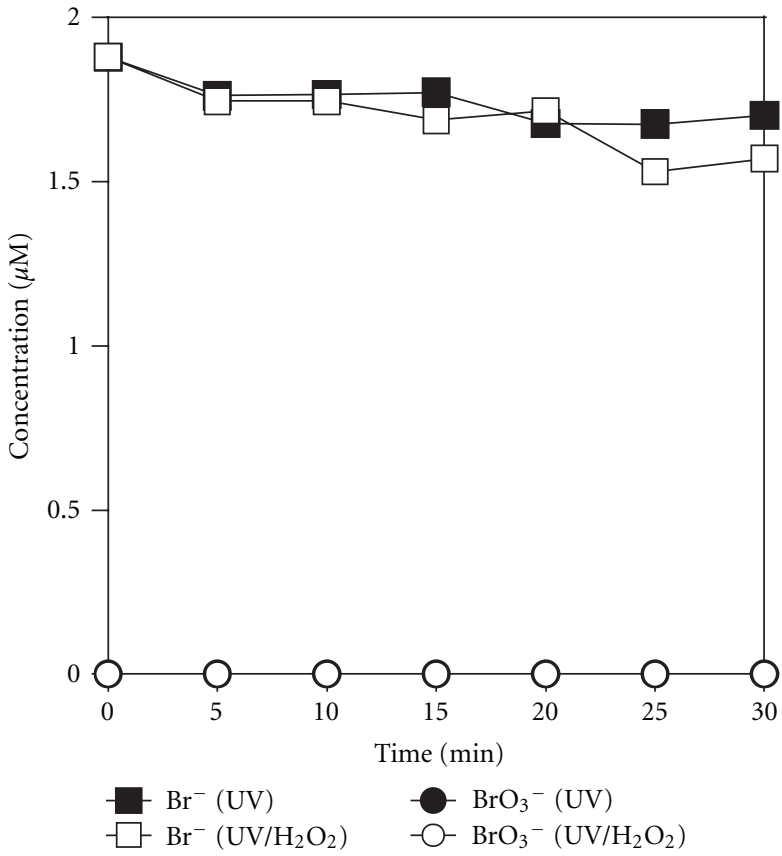

(a)

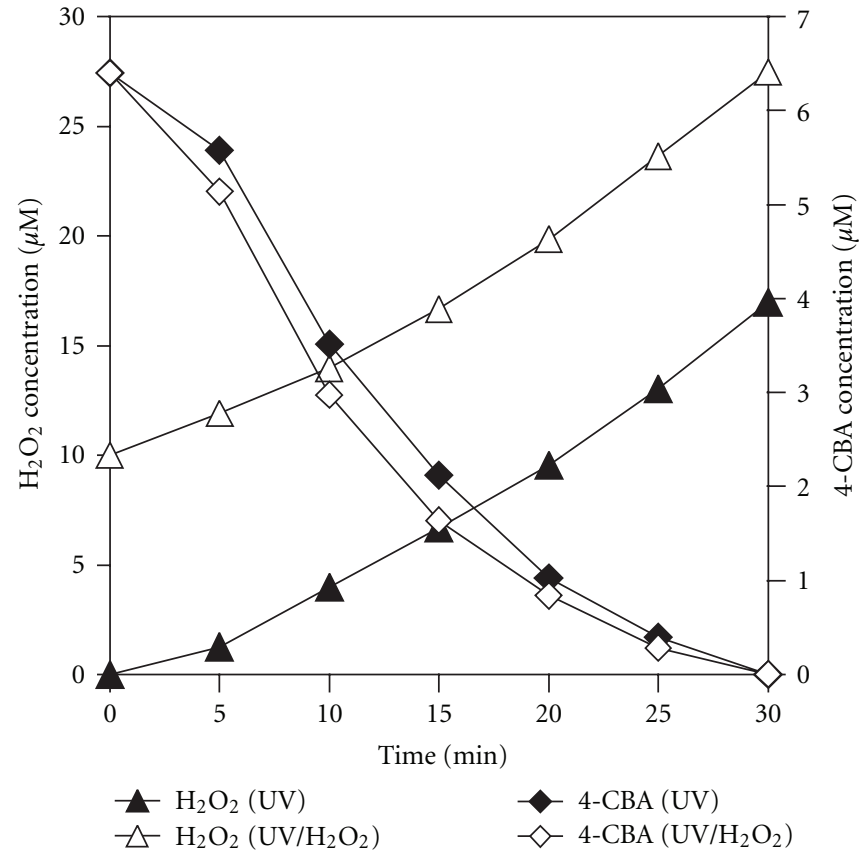

(b)

FIgURE 2: Changes in concentrations of $\mathrm{Br}^{-}, \mathrm{BrO}_{3}{ }^{-}, \mathrm{H}_{2} \mathrm{O}_{2}$, and 4-CBA during UV irradiation (UV) and $\mathrm{UV} / \mathrm{H}_{2} \mathrm{O}_{2}$ treatment at neutral pH. The initial $\mathrm{H}_{2} \mathrm{O}_{2}$ concentration for $\mathrm{UV} / \mathrm{H}_{2} \mathrm{O}_{2}$ was $10 \mu \mathrm{M}$.

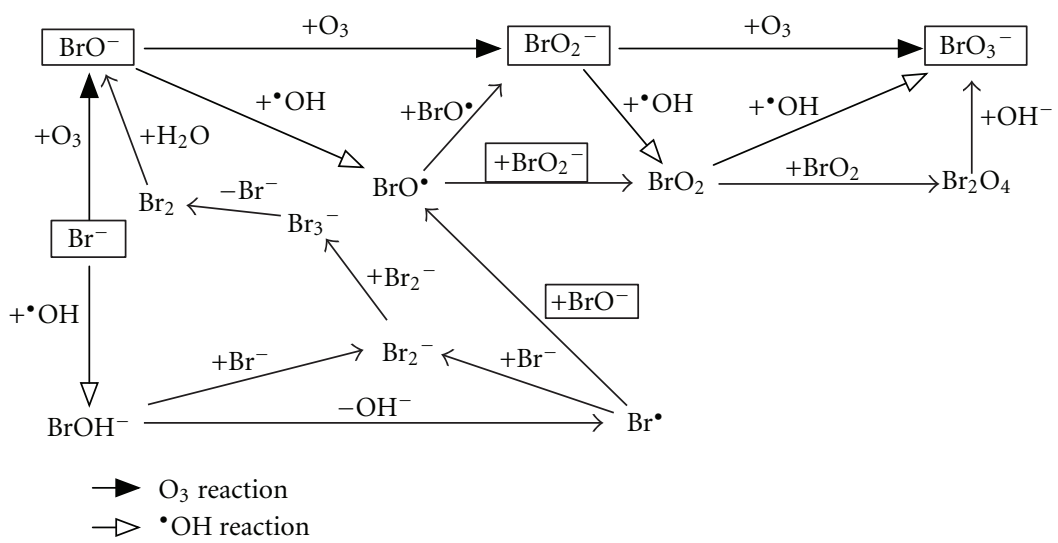

FIgURE 3: $\mathrm{BrO}_{3}{ }^{-}$formation pathways illustrated on the basis of Von Gunten and Oliveras [8].

acidification decreases the percentage of $\mathrm{BrO}^{-}$. The decrease in $\mathrm{BrO}^{-}$at acidic $\mathrm{pH}$ also contributed to the decrease in $\mathrm{BrO}_{3}{ }^{-}$formation [33]. In addition, the discordance of a decrement in $\mathrm{Br}^{-}$and an increment in $\mathrm{BrO}_{3}{ }^{-}$at acidic $\mathrm{pH}$ in Figure 4 suggested the accumulation of $\mathrm{HOBr}$.

3.3. $\mathrm{O}_{3} / \mathrm{H}_{2} \mathrm{O}_{2}$. Figure 5 shows the changes in concentrations of $\mathrm{Br}^{-}, \mathrm{BrO}_{3}{ }^{-}$, and 4-CBA during $\mathrm{O}_{3} / \mathrm{H}_{2} \mathrm{O}_{2}$ at various $\mathrm{H}_{2} \mathrm{O}_{2}$ doses and pHs. The $\mathrm{O}_{3} / \mathrm{H}_{2} \mathrm{O}_{2}$ processes showed additional effect on lowering $\mathrm{BrO}_{3}{ }^{-}$formation, especially at higher $\mathrm{H}_{2} \mathrm{O}_{2}$ dose. Bromate ion was not detected in $\mathrm{O}_{3} / \mathrm{H}_{2} \mathrm{O}_{2}$ at the $\mathrm{H}_{2} \mathrm{O}_{2}$ dose of $1,000 \mu \mathrm{M}$. When the $\mathrm{H}_{2} \mathrm{O}_{2}$ dose was lowered to 100 or $10 \mu \mathrm{M}$, rapid $\mathrm{BrO}_{3}{ }^{-}$formation was observed (Figure 5). As $\mathrm{H}_{2} \mathrm{O}_{2}$ can reduce $\mathrm{HOBr} / \mathrm{BrO}^{-}$into $\mathrm{Br}^{-}$, the excess $\mathrm{H}_{2} \mathrm{O}_{2}$ was believed to restrain $\mathrm{BrO}_{3}{ }^{-}$formation. The behavior of $\mathrm{BrO}_{3}{ }^{-}$formation in $\mathrm{O}_{3} / \mathrm{H}_{2} \mathrm{O}_{2}$ at the $\mathrm{H}_{2} \mathrm{O}_{2}$ dose of $10 \mu \mathrm{M}$ (Figure 5) was similar to that in ozonation (Figure 4), since $\mathrm{H}_{2} \mathrm{O}_{2}$ concentration in ozonation increased to around $10 \mu \mathrm{M}$, which was nearly equal to $\mathrm{H}_{2} \mathrm{O}_{2}$ concentration in $\mathrm{O}_{3} / \mathrm{H}_{2} \mathrm{O}_{2}$ at the $\mathrm{H}_{2} \mathrm{O}_{2}$ dose of $10 \mu \mathrm{M}$ (Figure 6). Thus, the initial $\mathrm{H}_{2} \mathrm{O}_{2}$ dose of $10 \mu \mathrm{M}$ was too low to restrain the $\mathrm{BrO}_{3}{ }^{-}$formation in this study.

When acidification was applied, $\mathrm{BrO}_{3}{ }^{-}$was not detected in $\mathrm{O}_{3} / \mathrm{H}_{2} \mathrm{O}_{2}$ at the $\mathrm{H}_{2} \mathrm{O}_{2}$ dose of $100 \mu \mathrm{M}$ or higher. This effect was caused by both the $\mathrm{HOBr} / \mathrm{BrO}^{-}$reduction by $\mathrm{H}_{2} \mathrm{O}_{2}$ 

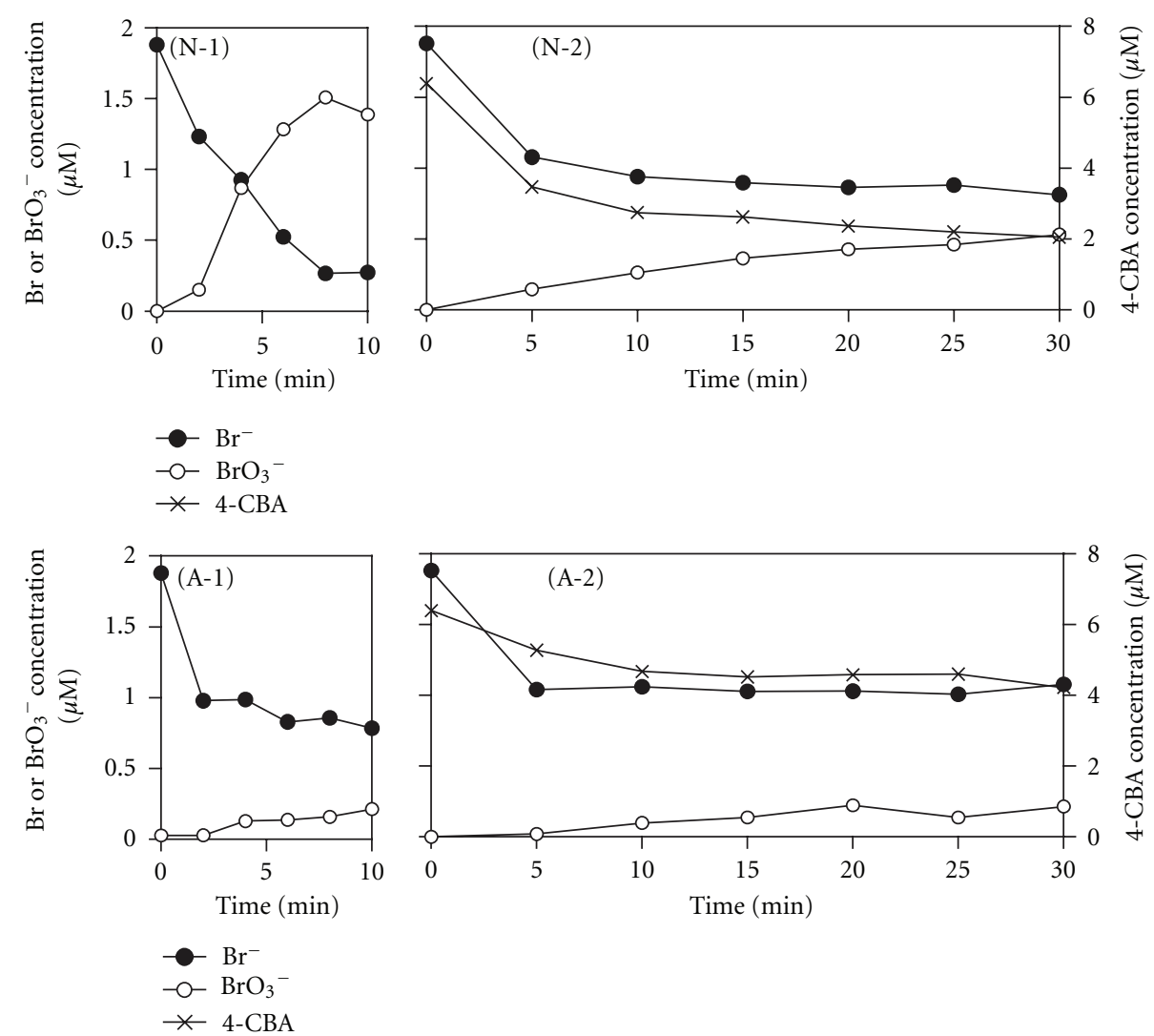

FIgURE 4: Changes in concentrations of $\mathrm{Br}^{-}, \mathrm{BrO}_{3}{ }^{-}$, and 4-CBA during ozonation at neutral $\mathrm{pH}$ without 4-CBA (N-1), ozonation at neutral $\mathrm{pH}$ with 4-CBA (N-2), ozonation at acidic $\mathrm{pH}$ without 4-CBA (A-1), and ozonation at acidic pH with 4-CBA (A-2).

and inhibition of $\cdot \mathrm{OH}$ generation in $\mathrm{O}_{3} / \mathrm{H}_{2} \mathrm{O}_{2}$. Because $\cdot \mathrm{OH}$ generation in $\mathrm{O}_{3} / \mathrm{H}_{2} \mathrm{O}_{2}$ is expressed by the following reactions [16] and the acidification inhibits the dissociation of $\mathrm{H}_{2} \mathrm{O}_{2}$ and $\mathrm{HO}_{2}$ (reactions (3) and (5)) as follows:

$$
\begin{gathered}
\mathrm{H}_{2} \mathrm{O}_{2} \longleftrightarrow \mathrm{H}^{+}+\mathrm{HO}_{2}{ }^{-} \\
\mathrm{O}_{3}+\mathrm{HO}_{2}{ }^{-} \longrightarrow \mathrm{O}_{3}{ }^{-}+\mathrm{HO}_{2}{ }^{-} \\
\mathrm{HO}_{2}{ }^{\bullet} \longleftrightarrow \mathrm{H}^{+}+{ }^{\bullet} \mathrm{O}_{2}{ }^{-} \\
\mathrm{O}_{3}+{ }^{\cdot} \mathrm{O}_{2}{ }^{-} \longrightarrow \mathrm{O}_{3}{ }^{-}+\mathrm{O}_{2} \\
\mathrm{O}_{3}{ }^{-}+\mathrm{H}^{+} \longleftrightarrow \mathrm{HO}_{3} \rightarrow \mathrm{O}_{2}+{ }^{\cdot} \mathrm{OH}
\end{gathered}
$$

The inhibition of $\bullet \mathrm{OH}$ generation in $\mathrm{O}_{3} / \mathrm{H}_{2} \mathrm{O}_{2}$ was also confirmed by a slow decrease in $4-\mathrm{CBA}$ at acidic $\mathrm{pH}$ (Figure 5).

3.4. $\mathrm{O}_{3} / U V$. Figure 7 shows changes in $\mathrm{Br}^{-}, \mathrm{BrO}_{3}{ }^{-}$, and 4CBA concentrations during $\mathrm{O}_{3} / \mathrm{UV}$. The $\mathrm{O}_{3} / \mathrm{UV}$ increased $\mathrm{BrO}_{3}{ }^{-}$concentration rapidly, even at the acidic $\mathrm{pH}$. However, the addition of 4-CBA successfully decreased the $\mathrm{BrO}_{3}{ }^{-}$ formation regardless of the $\mathrm{pH}$ condition. Collivignarelli and Sorlini [19] also observed lower $\mathrm{BrO}_{3}{ }^{-}$formation in $\mathrm{O}_{3} /$ UV than that in ozonation. As mentioned in the Section 3.2, the acidification decreases $\mathrm{BrO}_{3}{ }^{-}$formation by the inhibition of $\cdot \mathrm{OH}$ generation via the self-decomposition of ozone. Accordingly, it was thought that $\cdot \mathrm{OH}$ generated by the self-decomposition of ozone did not contribute to $\mathrm{BrO}_{3}{ }^{-}$ formation very much in $\mathrm{O}_{3} / \mathrm{UV}$. This discussion was supported by the lower concentration of dissolved ozone in $\mathrm{O}_{3} /$ UV (Figure 8). The low dissolved ozone concentration also brought the negligible contribution of molecular ozone to $\mathrm{BrO}_{3}{ }^{-}$formation. The decrease in $\mathrm{BrO}_{3}{ }^{-}$formation by the addition of 4-CBA indicated the contribution of ${ }^{\circ} \mathrm{OH}$ to $\mathrm{BrO}_{3}{ }^{-}$formation. Accordingly, it is suggested that the main oxidant in $\mathrm{O}_{3} / \mathrm{UV}$ was ${ }^{\bullet} \mathrm{OH}$, which mainly generated via UV photolysis of ozone [16]. The first step of ${ }^{\bullet} \mathrm{OH}$ generation in $\mathrm{O}_{3} / \mathrm{UV}$ is the production of $\mathrm{H}_{2} \mathrm{O}_{2}$ [16]. Then the $\mathrm{H}_{2} \mathrm{O}_{2}$ generates ${ }^{\circ} \mathrm{OH}$ through $\mathrm{UV}$ photolysis [16] and the same reactions as $\mathrm{O}_{3} / \mathrm{H}_{2} \mathrm{O}_{2}$ (reactions (3)-(7)). As the coexistence of dissolved ozone and ${ }^{\circ} \mathrm{OH}$ favors $\mathrm{BrO}_{3}{ }^{-}$formation $[13,17]$, low dissolved ozone concentration in $\mathrm{O}_{3} / \mathrm{UV}$ was thought to be advantageous to the depression of $\mathrm{BrO}_{3}{ }^{-}$formation. Moreover, strong $\mathrm{H}_{2} \mathrm{O}_{2}$ accumulation was observed during $\mathrm{O}_{3} / \mathrm{UV}$ (Figure 9). Therefore, the reduction of intermediates by $\mathrm{H}_{2} \mathrm{O}_{2}$ [15] and UV photolysis [30] was also inferred to contribute to the decline in the $\mathrm{BrO}_{3}{ }^{-}$formation potential.

3.5. Strategy for Organic Contaminants Removal with Preventing $\mathrm{BrO}_{3}{ }^{-}$Formation. The aim of advanced oxidation processes is organic contaminants removal from a water stream. Therefore, it is important to remove organic contaminants without $\mathrm{BrO}_{3}{ }^{-}$formation. In this context, $\mathrm{H}_{2} \mathrm{O}_{2}$ addition 

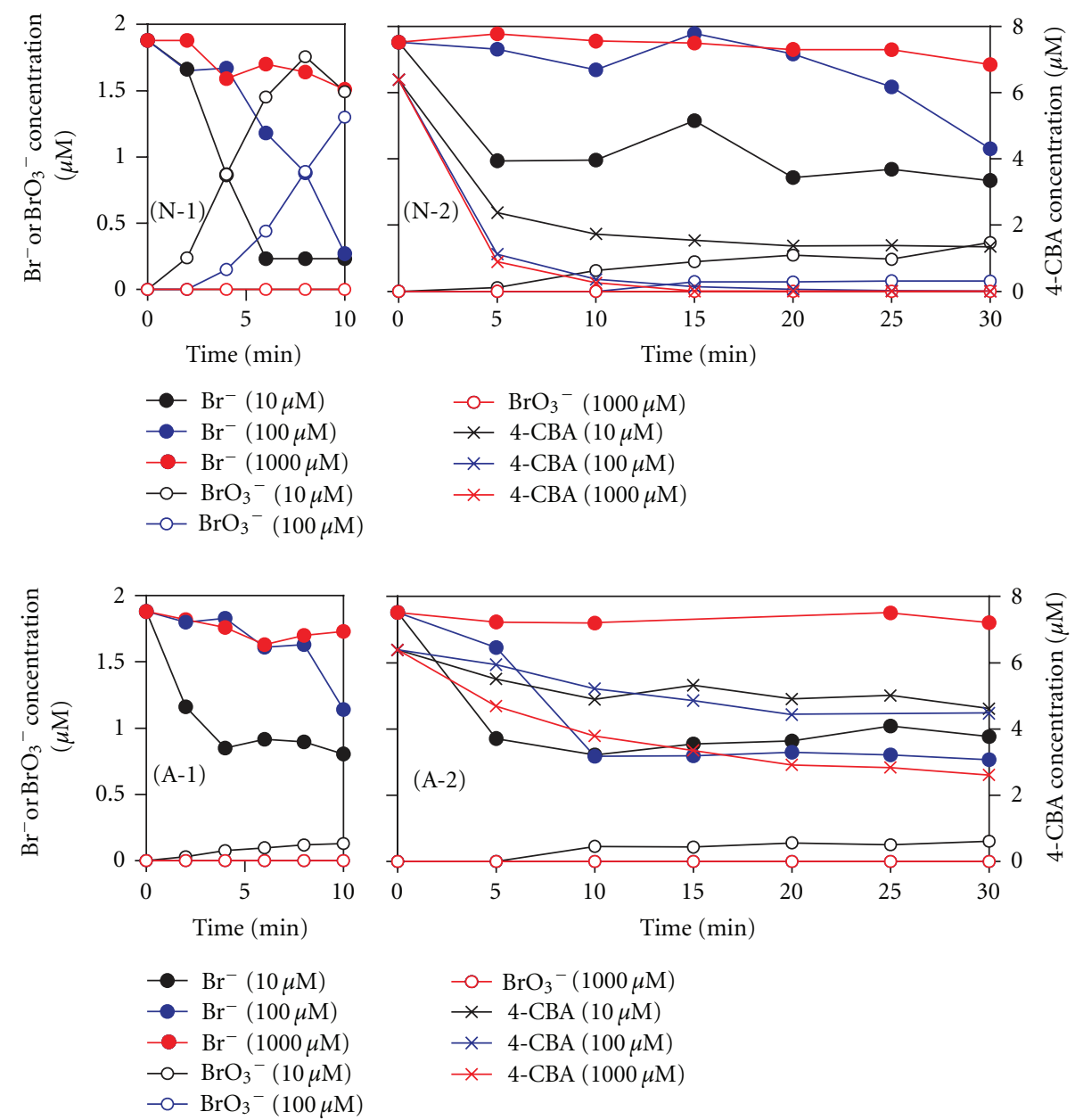

$$
\begin{aligned}
& -\circ \mathrm{BrO}_{3}^{-}(1000 \mu \mathrm{M}) \\
& * 4-\mathrm{CBA}(10 \mu \mathrm{M}) \\
& * \quad 4-\mathrm{CBA}(100 \mu \mathrm{M}) \\
& * \quad 4-\mathrm{CBA}(1000 \mu \mathrm{M})
\end{aligned}
$$

Figure 5: Changes in concentrations of $\mathrm{Br}^{-}, \mathrm{BrO}_{3}{ }^{-}$, and 4-CBA during $\mathrm{O}_{3} / \mathrm{H}_{2} \mathrm{O}_{2}$ at various $\mathrm{H}_{2} \mathrm{O}_{2}$ doses. The concentrations in the legend mean the $\mathrm{H}_{2} \mathrm{O}_{2}$ dose. The symbols in the bracket mean $\mathrm{O}_{3} / \mathrm{H}_{2} \mathrm{O}_{2}$ at neutral pH without 4-CBA (N-1), $\mathrm{O}_{3} / \mathrm{H}_{2} \mathrm{O}_{2}$ at neutral pH with 4-CBA $(\mathrm{N}-2), \mathrm{O}_{3} / \mathrm{H}_{2} \mathrm{O}_{2}$ at acidic $\mathrm{pH}$ without 4-CBA (A-1), and $\mathrm{O}_{3} / \mathrm{H}_{2} \mathrm{O}_{2}$ at acidic $\mathrm{pH}$ with 4-CBA (A-2).

is inapplicable to advanced water treatment, because it is not effective to degrade refractory organic matters like 4CBA. Ozonation is also difficult to apply to the organic contaminants removal, because it has higher $\mathrm{BrO}_{3}{ }^{-}$formation potential at the neutral $\mathrm{pH}$ than at the acidic $\mathrm{pH}$ as shown in Figure 4. Although the acidification successfully decreases the $\mathrm{BrO}_{3}{ }^{-}$formation potential of ozonation, it decreases the removal rate of organic contaminants too.

Contrary to $\mathrm{H}_{2} \mathrm{O}_{2}$ addition and ozonation, UV-based processes and $\mathrm{O}_{3} / \mathrm{H}_{2} \mathrm{O}_{2}$ are potentially applicable to advanced water treatment with inhibiting $\mathrm{BrO}_{3}{ }^{-}$formation. The UV irradiation and $\mathrm{UV} / \mathrm{H}_{2} \mathrm{O}_{2}$ successfully decompose organic contaminants without $\mathrm{BrO}_{3}{ }^{-}$formation. But their degradation rate of organic contaminants is not high, and $\mathrm{H}_{2} \mathrm{O}_{2}$ dose of $10 \mu \mathrm{M}$ is too low to enhance the degradation rate of UV irradiation. The $\mathrm{O}_{3} / \mathrm{H}_{2} \mathrm{O}_{2}$ is characterized by rapid degradation of organic contaminants and low $\mathrm{BrO}_{3}{ }^{-}$ formation rate at high $\mathrm{H}_{2} \mathrm{O}_{2}$ dose. Although the acidification effectuates further decrease in $\mathrm{BrO}_{3}{ }^{-}$formation, it spoils the degradation of organic contaminants. Therefore, the acidification should not apply to $\mathrm{O}_{3} / \mathrm{H}_{2} \mathrm{O}_{2}$. The feature of
$\mathrm{O}_{3} / \mathrm{UV}$ is rapid degradation of organic contaminants, low dissolved ozone concentration, and much $\mathrm{H}_{2} \mathrm{O}_{2}$ accumulation. As the $\mathrm{BrO}_{3}{ }^{-}$formation in $\mathrm{O}_{3} / \mathrm{UV}$ is restrained under the coexistence of organic contaminants, the $\mathrm{O}_{3} / \mathrm{UV}$ is applicable, if water contains sufficient quantity of organic contaminants. Figure 10 shows the relationship between $\mathrm{BrO}_{3}{ }^{-}$concentration and cumulative ozone consumption. Figure 10 demonstrates that $\mathrm{O}_{3} / \mathrm{UV}$ and $\mathrm{O}_{3} / \mathrm{H}_{2} \mathrm{O}_{2}$ at the $\mathrm{H}_{2} \mathrm{O}_{2}$ doses of 100 and $1,000 \mu \mathrm{M}$ were significantly decreased $\mathrm{BrO}_{3}{ }^{-}$formation per ozone consumption in comparison with ozonation and $\mathrm{O}_{3} / \mathrm{H}_{2} \mathrm{O}_{2}$ at the $\mathrm{H}_{2} \mathrm{O}_{2}$ dose of $10 \mu \mathrm{M}$. Kim et al. [17] reported that $\mathrm{BrO}_{3}{ }^{-}$concentration in $\mathrm{O}_{3} /$ $\mathrm{H}_{2} \mathrm{O}_{2}$ remained less than $10 \mu \mathrm{g} / \mathrm{L}$, when the molar ratio of $\mathrm{H}_{2} \mathrm{O}_{2}$ to ozone was above 0.5 . In our study of $\mathrm{O}_{3} / \mathrm{H}_{2} \mathrm{O}_{2}$ at the $\mathrm{H}_{2} \mathrm{O}_{2}$ dose of $100 \mu \mathrm{M}, \mathrm{BrO}_{3}{ }^{-}$was not produced at ozone consumption less than $250 \mu \mathrm{M}$. Thus, our result approximately accorded with the research by Kim et al. [17].

Consequently, if the concentration of organic contaminants is low, the UV irradiation and/or $\mathrm{UV} / \mathrm{H}_{2} \mathrm{O}_{2}$ are applicable to organic contaminants removal without $\mathrm{BrO}_{3}{ }^{-}$ formation, though it is necessary to beware nitrite formation 


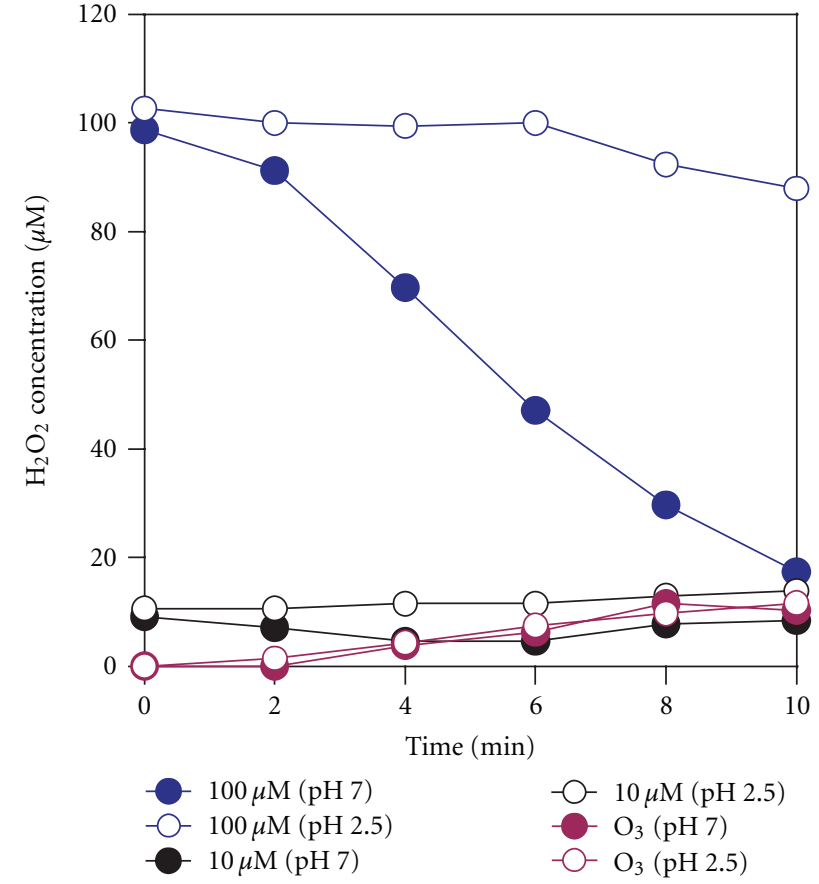

(a)

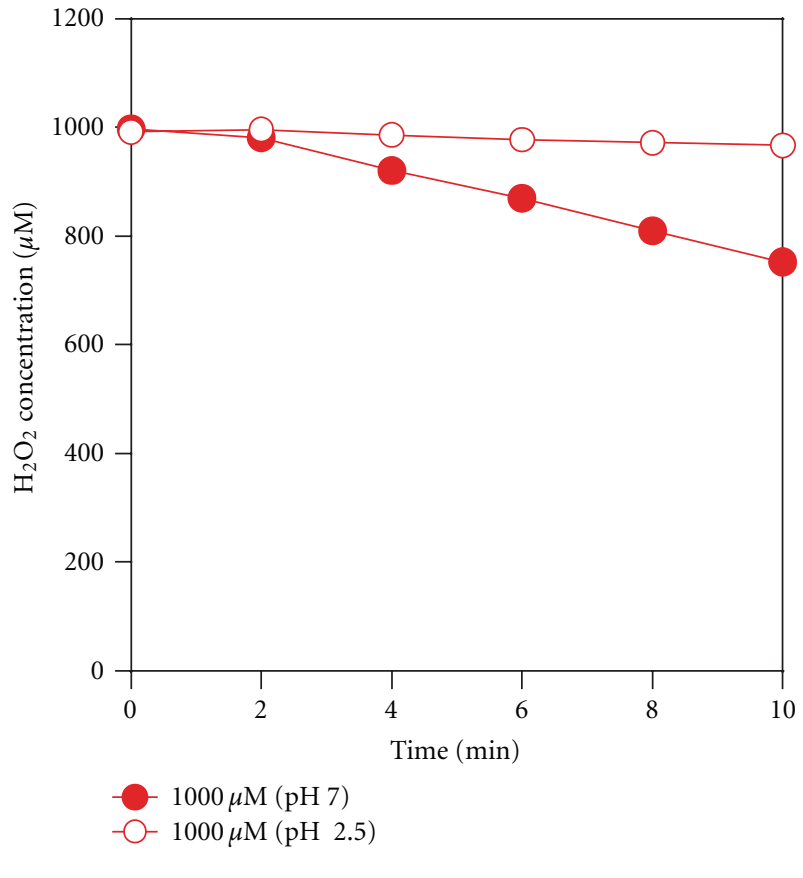

(b)

Figure 6: Changes in $\mathrm{H}_{2} \mathrm{O}_{2}$ concentrations during $\mathrm{O}_{3} / \mathrm{H}_{2} \mathrm{O}_{2}$ and ozonation without 4-CBA. The concentrations in the legend mean the $\mathrm{H}_{2} \mathrm{O}_{2}$ dose in $\mathrm{O}_{3} / \mathrm{H}_{2} \mathrm{O}_{2}$.
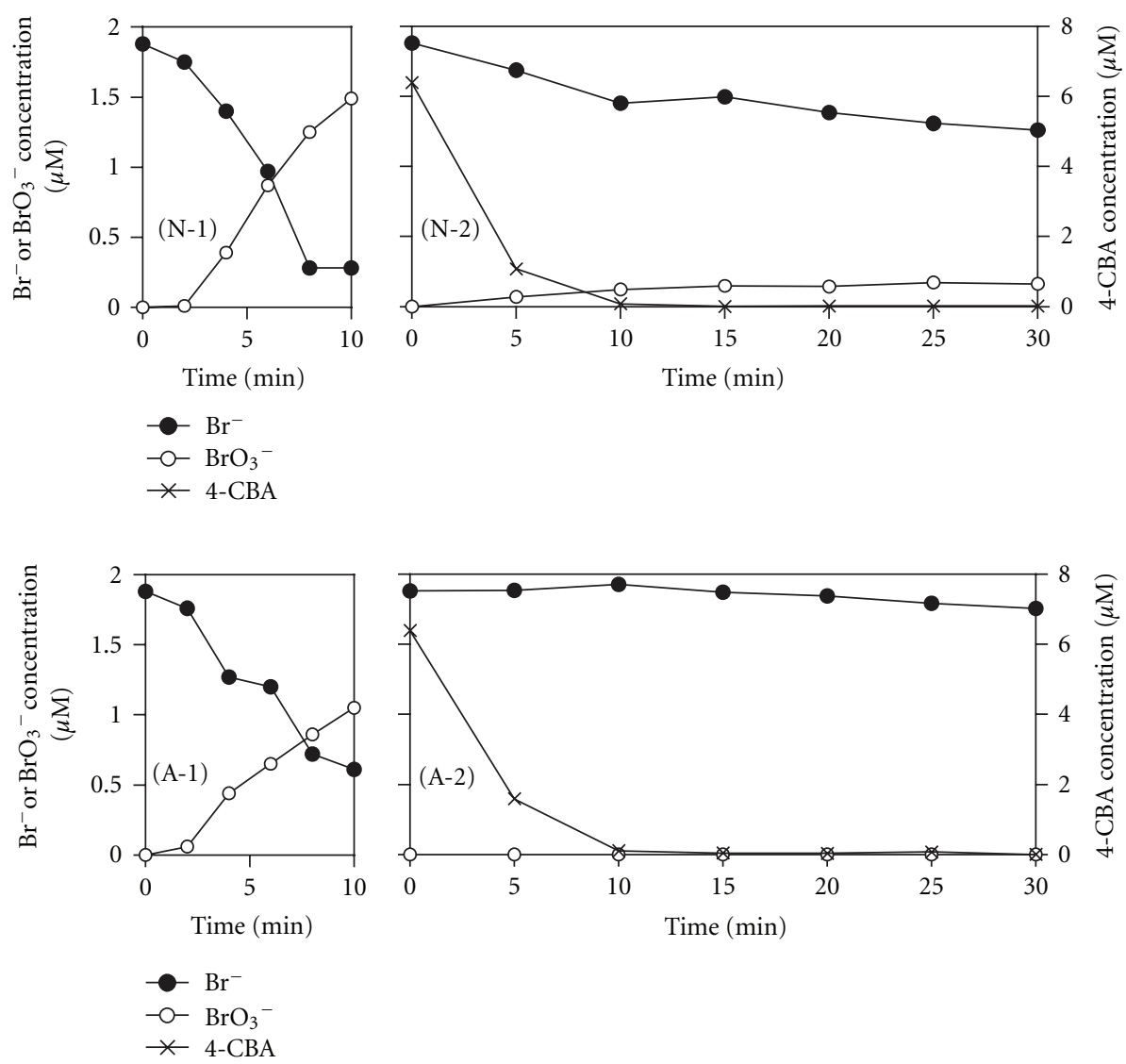

$-\mathrm{O}-\mathrm{BrO}_{3}^{-}$

Figure 7: Changes in concentrations of $\mathrm{Br}^{-}, \mathrm{BrO}_{3}{ }^{-}$, and 4-CBA during $\mathrm{O}_{3} / \mathrm{UV}$ at neutral $\mathrm{pH}$ without 4-CBA $(\mathrm{N}-1), \mathrm{O}_{3} / \mathrm{UV}$ at neutral $\mathrm{pH}$ with 4-CBA (N-2), $\mathrm{O}_{3} / \mathrm{UV}$ at acidic $\mathrm{pH}$ without 4-CBA (A-1), and $\mathrm{O}_{3} / \mathrm{UV}$ at acidic $\mathrm{pH}$ with 4-CBA (A-2). 


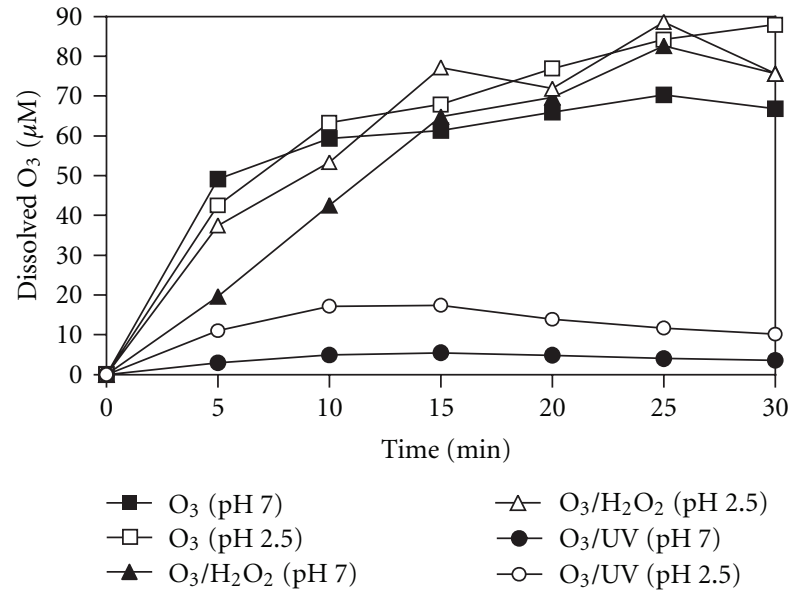

Figure 8: Changes in dissolved ozone concentrations during ozonation, $\mathrm{O}_{3} / \mathrm{H}_{2} \mathrm{O}_{2}$ (the $\mathrm{H}_{2} \mathrm{O}_{2}$ dose of $100 \mu \mathrm{M}$ ), and $\mathrm{O}_{3} / \mathrm{UV}$ with the addition of 4-CBA.

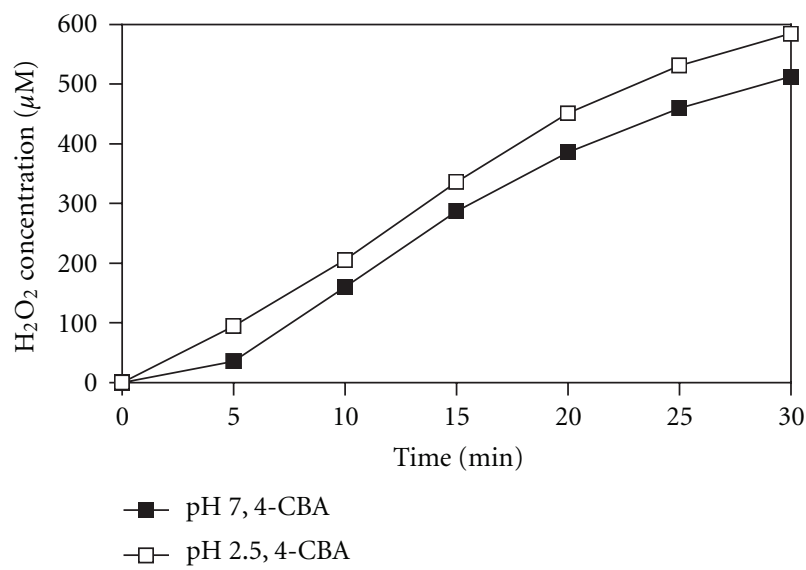

Figure 9: Changes in $\mathrm{H}_{2} \mathrm{O}_{2}$ concentrations during $\mathrm{O}_{3} / \mathrm{UV}$ with 4CBA.

during the treatment [34]. However, if the concentration of organic contaminants is high, $\mathrm{O}_{3} / \mathrm{H}_{2} \mathrm{O}_{2}$ and $\mathrm{O}_{3} / \mathrm{UV}$ should be discussed as advanced oxidation processes. When $\mathrm{O}_{3} /$ $\mathrm{H}_{2} \mathrm{O}_{2}$ is applied, the $\mathrm{H}_{2} \mathrm{O}_{2}$ dose should be more than the half of ozone consumption, because low $\mathrm{H}_{2} \mathrm{O}_{2}$ dose is ineffective for $\mathrm{BrO}_{3}{ }^{-}$control. When $\mathrm{O}_{3} / \mathrm{UV}$ is applied, the reaction time should be optimized, because extended reaction time increases the $\mathrm{BrO}_{3}{ }^{-}$formation potential. The real-time monitoring of UV absorbance of organic contaminants in water [35] may be effective in the optimum control of the reaction time of $\mathrm{O}_{3} / \mathrm{UV}$ without $\mathrm{BrO}_{3}{ }^{-}$formation.

\section{Conclusion}

In this research, $\mathrm{BrO}_{3}{ }^{-}$formation potential of UV irradiation, $\mathrm{H}_{2} \mathrm{O}_{2}$ addition, ozonation, $\mathrm{UV} / \mathrm{H}_{2} \mathrm{O}_{2}, \mathrm{O}_{3} / \mathrm{H}_{2} \mathrm{O}_{2}$, and $\mathrm{O}_{3} / \mathrm{UV}$ treatment were discussed for organic contaminants

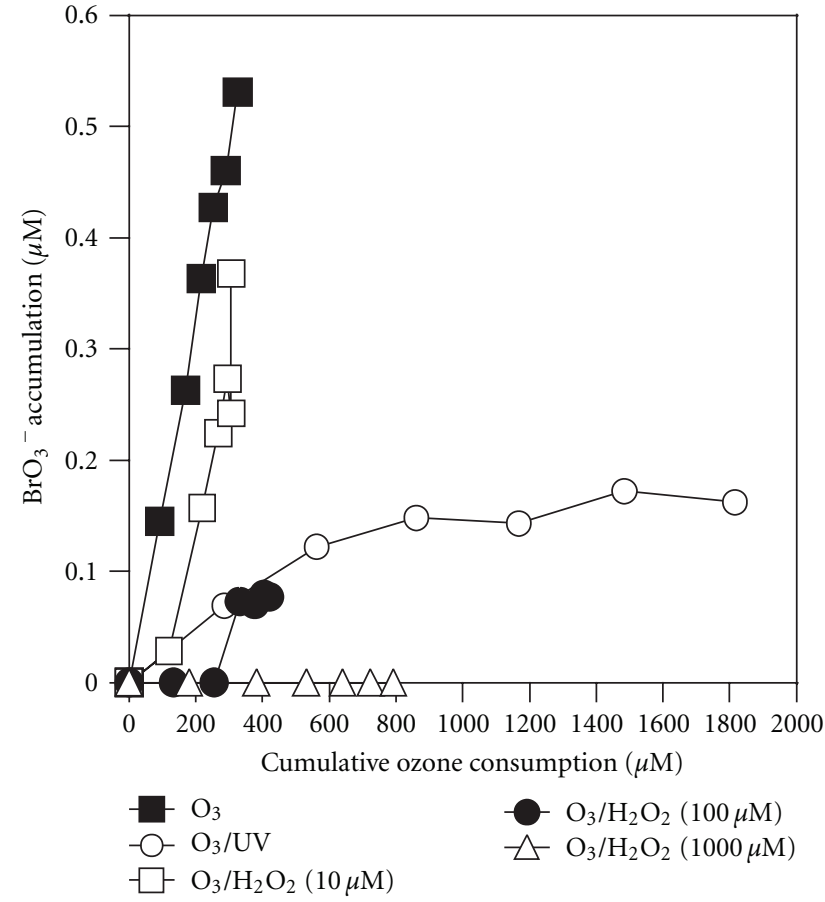

FIGURE 10: Relationship between cumulative ozone consumption and $\mathrm{BrO}_{3}{ }^{-}$accumulation during each treatment with 4-CBA addition at neutral $\mathrm{pH}$. Each treatment continued 30 minutes.

removal with restraining $\mathrm{BrO}_{3}{ }^{-}$formation using $\mathrm{KBr}$ solution with 4-CBA as a model refractory organic contaminant.

The UV irradiation, $\mathrm{H}_{2} \mathrm{O}_{2}$ addition, and $\mathrm{UV} / \mathrm{H}_{2} \mathrm{O}_{2}$ prevented $\mathrm{BrO}_{3}{ }^{-}$formation completely. However, $\mathrm{H}_{2} \mathrm{O}_{2}$ addition was inapplicable as advanced water treatment because of its weak oxidation ability. The UV irradiation and UV/ $\mathrm{H}_{2} \mathrm{O}_{2}$ could decompose the organic contaminant moderately. Ozonation produced the most $\mathrm{BrO}_{3}{ }^{-}$at neutral $\mathrm{pH}$. Although acidification could decrease the $\mathrm{BrO}_{3}{ }^{-}$formation, it also deteriorated the oxidation ability of ozonation. Therefore, it was thought to be difficult to apply ozonation to organic contaminants removal with restraining $\mathrm{BrO}_{3}{ }^{-}$formation. The $\mathrm{O}_{3} / \mathrm{H}_{2} \mathrm{O}_{2}$ successfully decreased $\mathrm{BrO}_{3}{ }^{-}$formation at the $\mathrm{H}_{2} \mathrm{O}_{2}$ doses of $100 \mu \mathrm{M}$ or higher. The degradation rate of 4-CBA was larger than the UV irradiation and $\mathrm{UV} / \mathrm{H}_{2} \mathrm{O}_{2}$. However, the behavior of $\mathrm{BrO}_{3}{ }^{-}$formation in the $\mathrm{O}_{3} / \mathrm{H}_{2} \mathrm{O}_{2}$ at the $\mathrm{H}_{2} \mathrm{O}_{2}$ dose of $10 \mu \mathrm{M}$ was similar to that in ozonation because of a deficiency of $\mathrm{H}_{2} \mathrm{O}_{2}$. The $\mathrm{O}_{3} /$ $\mathrm{UV}$ also showed rapid degradation of 4-CBA. Although it produced much $\mathrm{BrO}_{3}{ }^{-}$under the absence of 4-CBA, the $\mathrm{BrO}_{3}{ }^{-}$formation was strongly inhibited by the coexistence of 4-CBA. Consequently, if the concentration of organic contaminants is low, the UV irradiation and/or $\mathrm{UV} / \mathrm{H}_{2} \mathrm{O}_{2}$ are applicable to organic contaminants removal without $\mathrm{BrO}_{3}{ }^{-}$ formation. However, if the concentration of organic contaminants is high, $\mathrm{O}_{3} / \mathrm{H}_{2} \mathrm{O}_{2}$ and $\mathrm{O}_{3} / \mathrm{UV}$ should be discussed as advanced oxidation processes because of their higher organic removal efficiency. 


\section{References}

[1] C. Wu, C. Maurer, Y. Wang, S. Xue, and D. L. Davis, "Water pollution and human health in China," Environmental Health Perspectives, vol. 107, no. 4, pp. 251-256, 1999.

[2] A. Gadgil, "Drinking water in developing countries," Annual Review of Energy and the Environment, vol. 23, no. 1, pp. 253 286, 1998.

[3] O. A. Jones, J. N. Lester, and N. Voulvoulis, "Pharmaceuticals: a threat to drinking water?" Trends in Biotechnology, vol. 23, no. 4, pp. 163-167, 2005.

[4] R. Takanami, H. Ozaki, R. R. Giri, S. Taniguchi, and S. Hayashi, "Antiviral drugs zanamivir and oseltamivir found in wastewater and surface water in Osaka, Japan," Journal of Water and Environment Technology, vol. 10, pp. 57-68, 2012.

[5] D. Dotson, C. E. Rodoriquez, and K. G. Linden, "UV disinfection implementation status in US water treatment plants," Journal AWWA, vol. 104, pp. 77-78, 2012.

[6] B. L. Loeb, C. M. Thompson, J. Drago, H. Takahara, and S. Baig, "Worldwide ozone capacity for treatment of drinking water and wastewater: a review," Ozone: Science \& Engineering, vol. 34, pp. 64-77, 2012.

[7] I. Ali and V. K. Gupta, "Advances in water treatment by adsorption technology," Nature Protocols, vol. 1, no. 6, pp. 2661-2667, 2007.

[8] U. Von Gunten and Y. Oliveras, "Advanced oxidation of bromide-containig waters: bromate formation mechanisms," Environmental Science and Technology, vol. 32, no. 1, pp. 6370, 1998.

[9] D. Gerrity and S. Snyder, "Review of ozone for water reuse applications: toxicity, regulations, and trace organic contaminant oxidation," Ozone: Science and Engineering, vol. 33, no. 4, pp. 253-266, 2011.

[10] B. A. Wols and C. H. M. Hofman-Caris, "Review of photochemical reaction constants of organic micropollutants required for UV advanced oxidation processes in water," Water Research, vol. 46, pp. 2815-2827, 2012.

[11] IARC Monographs on the Evaluation of Carcinogenic Risks to Humans, vol. 73, International Agency for Research on Cancer, Lyon, France, 1999.

[12] M. S. Siddiqui and G. L. Amy, "Factors affecting DBP formation during ozone-bromide reactions," Journal of American Water Works Association, vol. 85, no. 1, pp. 63-72, 1993.

[13] K. Ozekin, P. Westerhoff, G. L. Amy, and M. Siddiqui, "Molecular ozone and radical pathways of bromate formation during ozonation," Journal of Environmental Engineering, vol. 124, no. 5, pp. 456-462, 1998.

[14] U. Pinkernell and U. von Gunten, "Bromate minimization during ozonation: mechanistic considerations," Environmental Science and Technology, vol. 35, no. 12, pp. 2525-2531, 2001.

[15] U. Von Gunten and Y. Oliveras, "Kinetics of the reaction between hydrogen peroxide and hypobromous acid: implication on water treatment and natural systems," Water Research, vol. 31, no. 4, pp. 900-906, 1997.

[16] W. H. Glaze, J. Kang, and D. H. Chapin, "The chemistry of water treatment processes involving ozone, hydrogen peroxide and ultraviolet radiation," Ozone: Science \& Engineering, vol. 9, pp. 335-352, 1987.

[17] H. S. Kim, H. Yamada, and H. Tsuno, "The control of brominated by-products and the removal of organic pollutants during the ozone/hydrogen peroxide treatment of secondary effluent," Ozone: Science and Engineering, vol. 29, no. 1, pp. 23-30, 2007.
[18] M. S. Siddiqui, G. L. Amy, and L. J. McCollum, "Bromate destruction by UV irradiation and electric arc discharge," Ozone: Science and Engineering, vol. 18, no. 3, pp. 271-290, 1996.

[19] C. Collivignarelli and S. Sorlini, "AOPs with ozone and UV radiation in drinking water: contaminants removal and effects on disinfection byproducts formation," Water Science and Technology, vol. 49, no. 4, pp. 51-56, 2004.

[20] T. Ratpukdi, F. Casey, T. Desutter, and E. Khan, "Bromate formation by ozone-VUV in comparison with ozone and ozone-UV: effects of pH, ozone dose, and VUV power," Journal of Environmental Engineering, vol. 137, no. 3, pp. 187-195, 2011.

[21] N. Kishimoto, Y. Morita, H. Tsuno, T. Oomura, and H. Mizutani, "Advanced oxidation effect of ozonation combined with electrolysis," Water Research, vol. 39, no. 19, pp. 46614672, 2005.

[22] N. Kishimoto, A. Kishimoto, and A. Nakayama, "Rapid removal of bromate ion from water streams with an electrolytic flow cell," Journal of Water Supply: Research and Technology-AQUA, vol. 61, pp. 103-110, 2012.

[23] Standard Methods for the Examination of Water \& Wastewater, American Public Health Association, Washington, DC, USA, 22nd edition, 2012.

[24] A. N. Baga, G. R. A. Johnson, N. B. Nazhat, and R. A. SaadallaNazhat, "A simple spectrophotometric determination of hydrogen peroxide at low concentrations in aqueous solution," Analytica Chimica Acta, vol. 204, pp. 349-353, 1988.

[25] J. P. Hoare, “4. Oxygen," in Standard Potentials in Aqueous Solution, A. J. Bard, R. Parsons, and J. Jordan, Eds., pp. 49-66, Mercel Dekker, New York, NY, USA, 1985.

[26] D. D. Dionysiou, M. T. Suidan, E. Bekou, I. Baudin, and J. M. Laîné, "Effect of ionic strength and hydrogen peroxide on the photocatalytic degradation of 4-chlorobenzoic acid in water," Applied Catalysis B, vol. 26, no. 3, pp. 153-171, 2000.

[27] N. Kishimoto, I. Somiya, and Y. Morita, "Dependence of hydroxyl radical production in $\mathrm{UV} / \mathrm{H}_{2} \mathrm{O}_{2}$ photo-oxidation on $\mathrm{UV}$ energy absorbed by aqueous solution," Advances in Asian Environmental Engineering, vol. 2, no. 2, pp. 8-17, 2002.

[28] J. Staehelin, R. E. Bühler, and J. Hoigné, "Ozone decomposition in water studied by pulse radiolysis. $\mathrm{OH}$ and $\mathrm{HO}_{4}$ as chain intermediates," Journal of Physical Chemistry, vol. 88, no. 24, pp. 5999-6004, 1984.

[29] J. C. Kruithof, P. C. Kamp, and M. Belosevic, " $U V / \mathrm{H}_{2} \mathrm{O}_{2}-$ treatment: the ultimate solution for pesticide control and disinfection," Water Science and Technology: Water Supply, vol. 2, no. 1, pp. 113-122, 2002.

[30] N. H. Phillip, E. Gürten, and V. Diyamandoğlu, "Transformation of bromine species during decomposition of bromate under UV light from low pressure mercury vapor lamps," Ozone: Science and Engineering, vol. 28, no. 4, pp. 217-228, 2006.

[31] M. S. Elovitz, U. Von Gunten, and H. P. Kaiser, "Hydroxyl radical/ozone ratios during ozonation processes. II. The effect of temperature, $\mathrm{pH}$, alkalinity, and DOM properties," Ozone: Science and Engineering, vol. 22, no. 2, pp. 123-150, 2000.

[32] W. R. Haag and J. Holgné, "Ozonation of bromide-containing waters: kinetics of formation of hypobromous acid and bromate," Environmental Science and Technology, vol. 17, no. 5, pp. 261-267, 1983.

[33] L. Xie and C. Shang, "A review on bromate occurrence and removal strategies in water supply," Water Science and Technology: Water Supply, vol. 6, no. 6, pp. 131-136, 2006. 
[34] A. J. Martijn and J. C. Kruithof, "UV and UV/ $\mathrm{H}_{2} \mathrm{O}_{2}$ treatment: the silver bullet for by-product and genotoxicity formation in water production," Ozone: Science \& Engineering, vol. 34, pp. 92-100, 2012.

[35] R. A. Dobbs, R. H. Wise, and R. B. Dean, "The use of ultraviolet absorbance for monitoring the total organic carbon content of water and wastewater," Water Research, vol. 6, no. 10, pp. 1173-1180, 1972. 


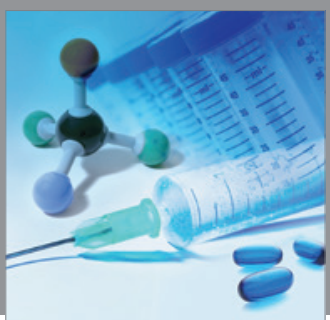

International Journal of

Medicinal Chemistry

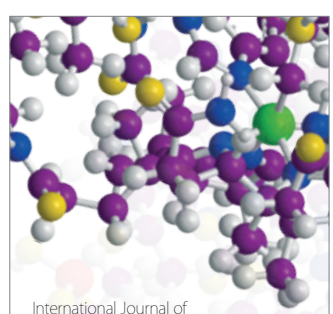

Carbohydrate Chemistry

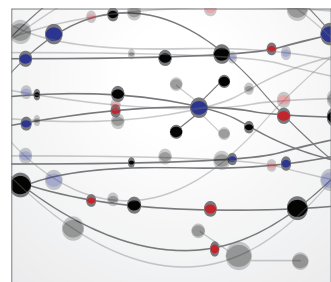

The Scientific World Journal
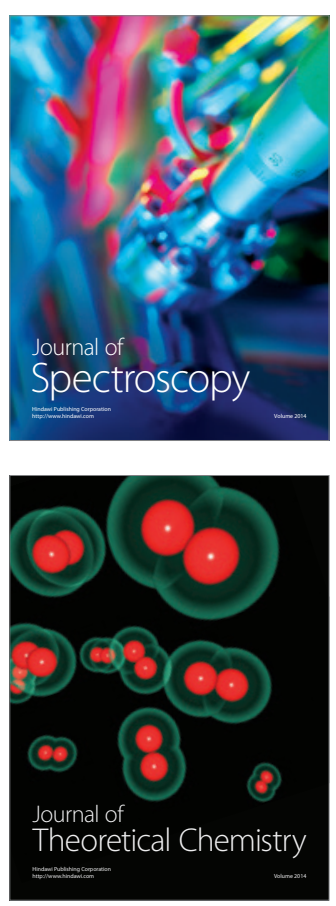
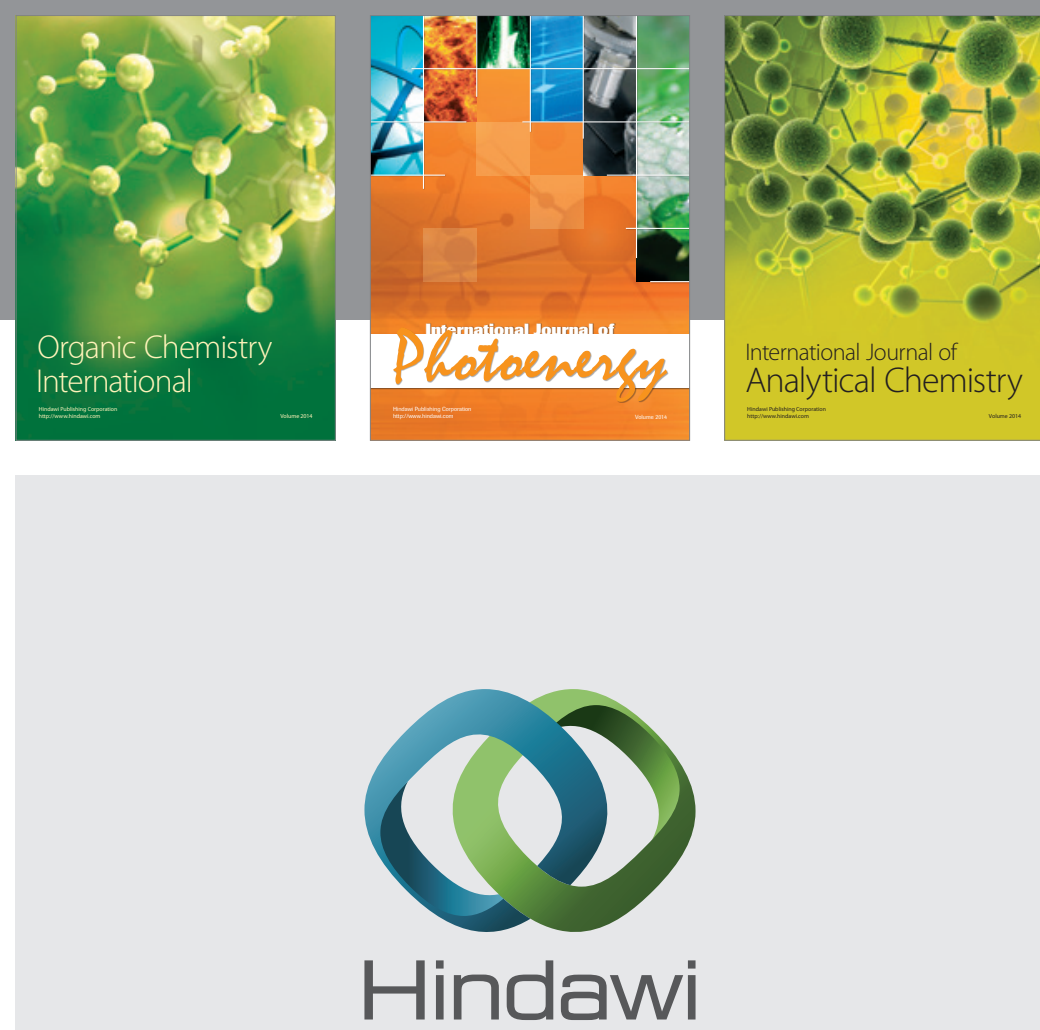

Submit your manuscripts at

http://www.hindawi.com
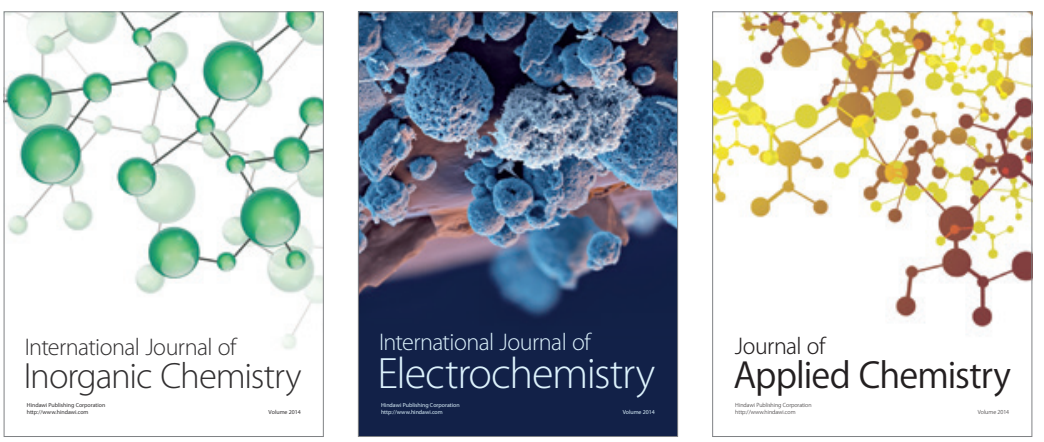

Journal of

Applied Chemistry
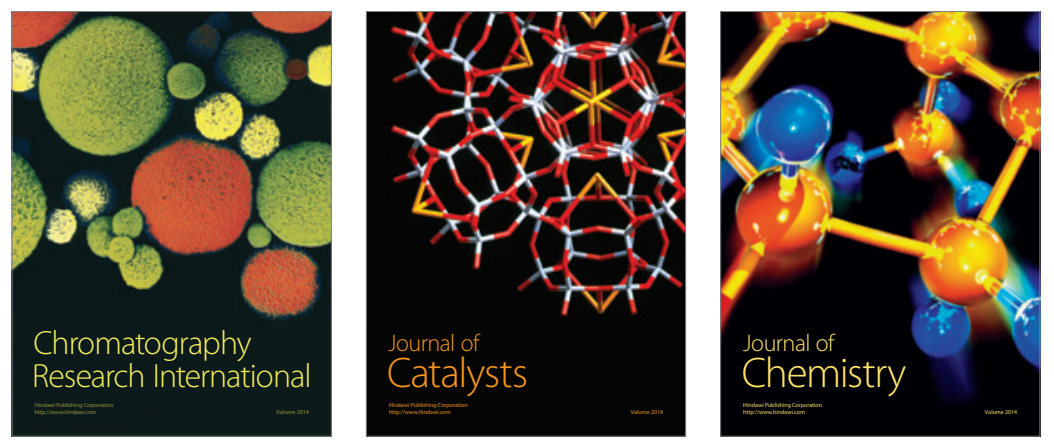
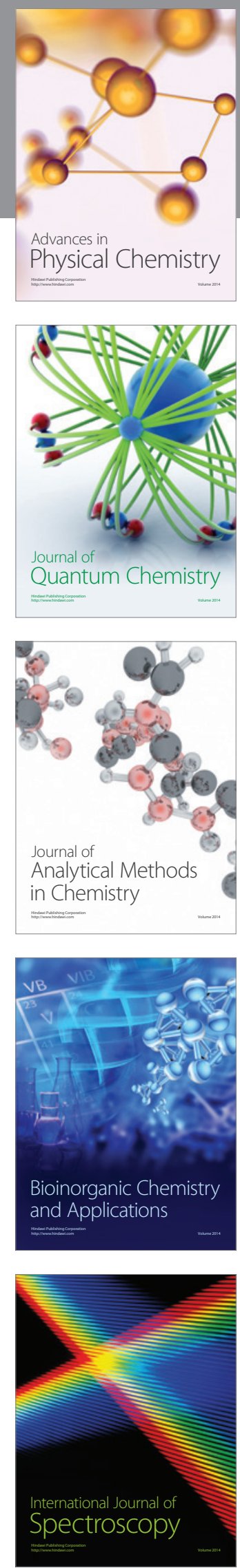